\title{
PENGARUH TEKNIK NAFAS DALAM TERHADAP PERUBAHAN TINGKAT KECEMASAN PADA IBU BERSALIN KALA I FASE AKTIF
}

\author{
${ }^{1}$ Sri Gustini \\ ${ }^{1}$ Dosen Poltekkes Kemenkes Tasikmalaya \\ Email:sri_eg2007@yahoo.co.id
}

\begin{abstract}
Abstrak
Penelitian ini bertujuan untuk mengetahui pengaruh teknik nafas dalam terhadap perubahan tingkat kecemasan pada ibu bersalin Kala I di Ruang VK RSUD dr. Slamet Garut. Metode penelitian yang digunakan adalah penelitian pre-eksperimental design dengan metode pendekatan one group pretest-postest design. Teknik pengambilan sampel secara accidental dari jumlah populasi ibu bersalin primi sebanyak 93 orang. Hasil uji statistik menunjukan sebelum dilakukan teknik nafas dalam sebagian besar responden mempunyai tingkat kecemasan berat, yaitu sebanyak 18 orang $(60,0 \%)$, dan setelah dilakukan teknik nafas dalam sebagian responden berubah kepada tingkat kecemasan rendah, yaitu sebanyak 17 orang $(56,7 \%)$. Hasil uji-T diketahui bahwa terdapat pengaruh yang signifikan antara teknik nafas dalam terhadap perubahan tingkat kecemasan ibu bersalin kala I fase aktif di Ruang VK RSUD dr. Slamet Garut. Berdasarkan hasil penelitian ini disarankan RSUD dr. Slamet Garut menerapkan asuhan tehnik nafas dalam pada setiap ibu bersalin yang bertujuan untuk mengurangi ketakutan dan kecemasan.
\end{abstract}

Kata Kunci: teknik nafas dalam, tingkat kecemasan

\begin{abstract}
This study aims to determine the influence of deep breathing techniques to changes in the level of anxiety on maternal tense I active phase. The research method used a pre-eperimental design, with one group pretest-postest design. The sampling techniques used accidental with a primi maternal population of 93 people. Statistical test results showed before to do deep breathing techniques most respondents have severe anxiety level as many as 18 people (60,0\%) and after deep breathing techniques some of the respondents changed to lower anxiety levels, as many as 17 people (56,7\%). Conclusion by used the T-Test, showed that there were significant effects of deep breathing techniques to change in the level of anxiety on maternal tense I active phase at the VK room in dr. Slamet Garut hospital. Based on the results of this study suggested dr. Slamet Garut Hospital apply deep breathing techniques in the care of mother who will face each delivery that aims to reduce fear and anxiety.
\end{abstract}

Keyword: Deep breathing techniques, the level of anxiety

\section{PENDAHULUAN}

Persalinan merupakan hal yang fisiologis atau normal (Wenny, 2011), namun dapat berubah menjadi abnormal apabila tidak ditangani dengan baik (Asri, 2010). Wanita yang menghadapi proses persalinan biasanya mengalami stres, takut, cemas, serta panik (Nurul, 2010). Seorang primigravida dalam menghadapi persalinan sebagian besar selalu mengalami kecemasan. Kecemasan ini terjadi karena berbagai faktor. Kecemasan itu sendiri adalah ketegangan, rasa tidak aman dan kekawatiran yang timbul karena dirasakan terjadi sesuatu yang tidak menyenangkan (Depkes, 2002). Kecemasan dan ketakutan dalam persalinan dapat menyebabkan kontraksi uterus tidak teratur, kontraksi uterus yang terlalu kuat (Chamidon, 2005), pembuluh darah mengalami vasokontriksi atau menyempit (Wenny, 2011), akibatnya membahayakan janin karena pemberian oksigen ke janin berkurang, sehingga terjadi asfiksia dan tidak jarang berakhir dengan kematian janin, apabila kala I gagal, karena gangguan psikis akan terjadi pemerasan 
tenaga ekstra untuk mengejan (Chamidon, 2005).

Penelitian yang dilakukan oleh Felman,et,al (Aryasatiani, 2005) menemukan lebih dari $12 \%$ ibu ibu yang pernah melahirkan mengatakan bahwa mereka mengalami cemas pada saat melahirkan. Dinas Kesehatan Provinsi Jawa Barat bersama RS Jiwa Bandung, RS Jiwa Cimahi, dan Bagian Psikiatri Fakultas Kedokteran Universitas Padjajaran (FKUP)/ Rumas Sakit Hasan Sadikin (RSHS) tahun 2010 melakukan survei kesehatan jiwa pada ibu inpartu di 112 puskesmas 24 kabupaten Provinsi Jawa Barat. Hasil penelitian ini menunjukkan, 798 orang atau $(27 \%)$ dari 2.928 responden ibu inpartu, menunjukkan tanda gangguan psikiatri berupa kecemasan atau ansieta (Republika, 2010). Kecemasan dan ketegangan yang dialami oleh ibu saat persalinan membuat fungsi tubuh secara umum mengalami perubahan seperti otot menjadi tegang (Wenny, 2011).

Salah satu cara penatalaksanaan nonfarmakologis untuk mengurangi nyeri dan cemas pada saat persalinan dengan relaksasi. Relaksasi merupakan kegiatan untuk mengendurkan ketegangan, pertama ketegangan jasmaniah yang nantinya akan berdampak pada penurunan ketegangan jiwa (Wiramihardja, 2006). Terdapat macammacam metode relaksasi, satu diantaranya metode relaksasi pernafasan, yaitu teknik nafas dalam. Teknik ini merupakan cara pernafasan tenang dan irama teratur yang akan memicu relaksasi (Eileen, 2008). Tubuh yang relaks membuat pikiran relaks, yang pada akhirnya membantu mengurangi ketegangan psikis yang disebabkan oleh kecemasan atau ketakutan (Penny,et,al,2010).

Menurut survey pendahuluan yang dilakukan peneliti pada tanggal 29 Januari 2013 di Ruang VK RSUD dr. Slamet Garut dengan metode wawancara menggunakan skala kecemasan HARS pada 12 orang ibu bersalin kala I. Sebanyak 12 orang ibu bersalin kala I tersebut didapatkan data tingkat kecemasan yang dialami ibu; $16 \%$ orang mengalami kecemasan berat, $66 \%$ orang mengalami kecemasan sedang, $18 \%$ orang mengalami kecemasan ringan. Sebagian besar ibu bersalin tersebut mengatakan bahwa mereka takut akan menghadapi persalinan, takut akan keselamatan bayi dan dirinya dan takut akan komplikasi yang bisa terjadi selama proses persalinan berlangsung semua ini menjadi penyebab kecemasan yang dialami ibu dalam menghadapi persalinan. Berdasarkan uraian tersebut maka dilakukan penelitian mengenai pengaruh teknik nafas dalam terhadap perubahan tingkat kecemasan ibu bersalin kala I fase aktif di Ruang VK RSUD dr.Slamet Garut.

\section{METODE PENELITIAN}

Penelitian ini merupakan penelitian preeksperimental design dengan pendekatan one group pretest-posttest design. Populasi dalam penelitian ini adalah 93 orang ibu bersalin primi yang ada di ruang VK RSUD dr. Slamet Garut. Pengambilan sampel secara aksidental dan memenuhi syarat kriteria sampel. Kriteria inklusi penelitian diantaranya adalah ibu bersalin kala I fase aktif mulai dari pembukaan 4-9 cm, komunikatif, bersedia menjadi responden.

Instrumen yang dipakai untuk mengetahui tingkat kecemasan pada ibu bersalin kala I berupa lembar observasi atau pertanyaan sebanyak 35 butir pertanyaan, jawaban responden yang ada diklasifikasikan menjadi tiga kategori yaitu cemas rendah dengan skala nilainya $0-8$, cemas sedang bila nilainya 9-16 dan cemas berat nilainya $>16$ (skala kecemasan Hamilton). Instrumen tingkat kecemasan sebelumnya telah dilakukan uji validitas dan reliabilitas di VK RSUD Kota Tasikmalaya.

Hasil uji validitas menunjukkan bahwa setiap pertanyaan mengenai kecemasan sebanyak 35 item, menyatakan 30 item pertanyaan layak untuk diujikan, dimana item no. $21 r$ hitung menunjukkan -0.193 (tidak valid), item no. $29 r$ hitung $=0.100$ (tidak valid), item no. $r$ hitung $=-0.097$ (tidak valid), item no. $32 \mathrm{r}$ hitung $=0.067$ (tidak valid), dan item no. $33 r$ hitung $=-0.248$ (tidak valid). Uji reliabilitas dilakukan dengan uji Alpha 
Cronbach. Hasil uji reliabilitas menunjukkan reliabel, karena nilai alpha cronbach $>0.7$, sedangkan nilai alpha cronbach yang didapat adalah 0.852 lebih besar dari 0.7 , maka dapat dikatakan kuesioner tersebut reliabel (Sugiyono, 2010).

Data diolah melalui tahapan editing (edit data), coding (pengkodean), entry (input data) dan tabulating (menghitung). Analisis dilakukan melalui analisis univariat dan bivariat. Analisis bivariat dengan metode pre test dan post test menggunakan uji-T.

\section{HASIL PENELITIAN}

Berdasarkan hasil penelitian pada ibu bersalin kala I di ruang VK RSUD dr. Slamet Garut dalam pengaruh terhadap perubahan tingkat kecemasan sebelum dan setelah dilakukan teknik nafas dalam, diperoleh data sebagai berikut;

Tabel 1. Rerata skor kecemasan Ibu Bersalin Kala I di Ruang VK RSUD dr. Slamet Garut

\begin{tabular}{cccc}
\hline Kecemasan & Mean & T & p-value \\
\cline { 1 - 2 } Pre Tes & 16,63 & \multirow{2}{*}{7,781} & 0,001 \\
\cline { 1 - 2 } Post Tes & 10,93 & & \\
\hline
\end{tabular}

Dari tabel 1. dapat diketahui bahwa untuk pre test diperoleh nilai rata-rata sebesar 16,63 dan post test diperoleh nilai rata-rata 10,93. Berdasarkan hasil uji $\mathrm{T}$ didapatkan nilai $\mathrm{T}=$ 7,781 , dan nilai $p$-value sebesar 0,001 . Karena nilai $\mathrm{p}$-value $<\alpha(0,05)$, maka $\mathrm{H}_{0}$ ditolak. Kesimpulannya terdapat pengaruh yang signifikan dari teknik nafas dalam terhadap tingkat kecemasan ibu bersalin kala I di ruang VK RSUD dr. Slamet Garut.

\section{PEMBAHASAN}

Pada awal sebelum dilakukan teknik nafas dalam, terdapat 12 orang yang mempunyai kecemasan sedang dan 18 orang yang mempunyai kecemasan berat. Hal ini bisa disebabkan proses persalinan yang akan menimbulkan ketegangan dan kecemasan, ketakutan menghadapi proses persalinan, tidak sanggup menahan rasa mules, dan khawatir dengan keadaan janin.

Hasil observasi yang didapat dari penelitian ini pada primigravida rata-rata mengalami cemas berat dikarenakan proses persalinan merupakan hal yang baru bagi mereka. Wanita cemas terhadap kemungkinan-kemungkinan komplikasi persalinan, nyeri waktu persalinan (Kartono, 2007), apalagi pernah mendengar trauma atau kegagalan dalam menghadapi persalinan, menganggap masa inpartu itu berat dan menjadi beban, kurang percaya diri bahwa akan sanggup menghadapi persalinan (Yessi, 2010).

Setelah diberikan teknik nafas dalam, tingkat kecemasan ibu bersalin kala I mengalami perubahan, yakni dimana menjadi 17 orang mempunyai kecemasan rendah, 8 orang mempunyai kecemasan sedang dan 5 orang mempunyai kecemasan berat. Penurunan kecemasan tersebut mungkin disebabkan oleh pemberian teknik relaksasi sederhana yakni nafas dalam.

Menurut Smeltzer dan Bare (2002), teknik relaksasi nafas dalam merupakan suatu bentuk asuhan yang dalam hal ini perawat/bidan mengajarkan kepada klien bagaimana cara melakukan nafas dalam dan lambat untuk meningkatkan ventilasi alveoli, memelihara pertukaran gas serta mengurangi stress baik stress fisik maupun emosional yaitu menurunkan intensitas nyeri dan kecemasan.

Proses persalinan merupakan salah satu faktor yang dapat menimbulkan kecemasan, karena proses melahirkan bayi tidak selalu bersifat somatik akan tetapi juga bersifat psikomatis. Sebab banyak psikis ikut memiliki kelancaran atau keterlambatan proses melahirkan bayi tersebut atau juga mempercepat kelahiran bayi maka fungsi biologis dari reproduksi sangat dipengaruhi oleh kehidupan psikis dan kehidupan emosional wanita yang bersangkutan (Kartono, 2007).

Usaha yang perlu dilakukan adalah mendidik calon ibu untuk menghilangkan rasa takutnya dan berusaha untuk meyakinkan bahwa kehamilan dan persalinannya merupakan hal yang normal dan wajar (Nolan, 2003). Chamidoen (2005) mengatakan usaha pembinaan kesehatan mental ini dapat dilakukan oleh dokter, bidan, orang-orang disekitarnya. 
Simkin \& Ancheta (2005) mengatakan penggunaan tindakan kenyamanan fisik yang sederhana dapat meningkatkan perasaan menguasai, mengurangi kecemasan, diantaranya dapat melakukan menghitung nafasnya satu persatu, untuk menolong wanita mengetahui kemajuan persalinan dengan memberikan informasi, membantu dan mengarahkan untuk relaksasi, kata-kata pujian dan dorongan, berbicara dengan suara bernada rendah secara berirama.

Hasil analisis menunjukkan bahwa pemberian teknik nafas dalam memberikan pengaruh terhadap penurunan kecemasan yang dialami oleh ibu bersalin secara bermakna. Kecemasan ini dapat dikurangi dengan jalan mengatur nafas secara dalam, lambat atau perlahan yang menjadikan badan dan fikiran menjadi relaksasi (Smeltzer dan Bare, 2002).

Pernafasan dikendalikan secara otomatis oleh pusat pernafasan di otak, dan dapat dikendalikan oleh kendali volunter. Pusat pernafasan berespons terhadap kadar karbon dioksida yang mengalir melalui pusat tersebut. Faktor lain yang mempengaruhi pusat pernafasan adalah ketakutan, kecemasan, rasa gembira yang meluap, marah, frustasi serta rasa nyeri. Kebanyakan dari gejala ini akan muncul saat persalinan bersamaan dengan timbulnya kontraksi. Kecemasan dan ketakutan dalam persalinan dapat menngakibatkan kontraksi uterus tidak teratur (Chamidoen, 2005).

Kontraksi uterus yang kuat menyebabkan kondisi menggunakan oksigen dan menghasilkan karbon dioksida yang berlebihan, namun tubuh secara otomatis akan memperbaiki kondisi ini. Tetapi, bila ibu memperlihatkan kondisi yaitu pernafasan yang dalam dan cepat, maka ia berada dalam kondisi bahaya karena dapat mengalami hiperventilasi atau sesak nafas yang merupakan gejala kecemasan. Gejalanya seperti pusing, pucat, berkeringat, palpitasi dan kesemutan daerah ekstremitas.

Menarik nafas dalam dan perlahan, saat persalinan memfasilitasi alveolar, yang dapat meningkatkan asupan oksigen serta menurunkan kadar karbon dioksida sesuai keperluan. Teknik relaksasi dan pernafasan merupakan hal yang sangat erat kaitannya dengan peningkatan asupan oksigen. Kedua metode ini dapat mencegah hiperventilasi yang merupakan gejala kecemasan dan melatih teknik relaksasi.

\section{KESIMPULAN}

Terdapat pengaruh teknik nafas dalam terhadap perubahan tingkat kecemasan ibu bersalin kala I fase aktif di ruang VK RSUD dr. Slamet Garut dengan nilai p-value 0,001. Melakukan teknik relaksasi nafas dalam ini mempunyai keuntungan baik secara emosional maupun psikologis.

\section{REFERENSI}

Anggraeni D., (2012). Melahirkan Tanpa Rasa Sakit. cetakan pertama. Galmas Publisher. Klaten

Bagian Obsteri dan Ginekologi FK Universitas Padjajaran, (2003). Obstetri Fisiologi. Elemen. Bandung

Brayshaw E., (2008). Senam Hamil \& Nifas Pedoman Praktis Bidan. alih bahasa Ramona P. Kapoh. cetakan pertama. EGC. Jakarta

Bobak, (2005). Keperawatan Maternitas. Edisi ke 4. EGC. Jakarta

Chamidoen K., (2005). Aspek Kejiwaan Dalam Kebidanan. cetakan keempat. Jakarta

Chomaria N., (2010). Panduan Terlengkap Kehamilan bagi Muslimah. cetakan pertama. Cinta. Surakarta

Dahlan M., (2010). Statistic untuk Kedokteran dan Kesehatan. Salemba Medika. Jakarta

Depkes RI., (2002). Pedoman Pelayanan Kebidanan Dasar. Departemen Kesehatan RI. Jakarta

Hidayat A., (2010). Asuhan Kebidanan Persalinan. Nuha Medika. Yogyakarta

Judha M., (2012). Teori Pengukuran Nyeri dan Nyeri Persalinan. Nuha Medika. Jakarta

Kartini K., (2007). Psikologi Wanita. Jilid 2. Mandar Maju. Bandung

Nisman W., (2011). Ternyata Melahirkan Itu Mudah dan Menyenangkan. edisi pertama. Andi. Yogyakarta 
Nursalam, (2003). Konsep Penerapan Metodologi Penelitian IImu Keperawatan. edisi pertama. Salemba Medika. Jakarta Notoatmodjo S., (2005). Metode Penelitian Kesehatan. Rineka Cipta. Jakarta

Oxorn H., (2003). IImu Kebidanan : Patologi dan Fisiologi Persalinan (Human Labour and Birth). Yayasan Essentia Medica. Jakarta

Prawihardjo S., (2006). Ilmu Kebidanan. Yayasan Bina Pustaka Sarwono Prawihardjo. Jakarta

Priharjo. R., (2003). Perawatan Nyeri. EGC. Jakarta

Simkin, \& Ancheta, (2005). Buku Saku Persalinan. EGC. Jakarta

Simkin,et,al., (2010). Panduan Lengkap Kehamilan, Melahirkan, dan Bayi. edisi revisi. Arcan. Jakarta

Smeltzer, and Bare., (2002) Buku Ajar Keperawatan Medikal Bedah Brunner \& Sudaarth. vol.1. ed.8. Alih Bahasa : Monica E. Ellen P. EGC. Jakarta

Stuart W., (2008). Buku Saku Keperawatan Jiwa. EGC. Jakarta

Sugiyono, (2010). Metode Penelitian Pendidikan Pendekatan Kuantitatif. Kualitatif. dan R\&D. cetakan ke sebelas. Alfabeta. Bandung

Videbeck L., (2008). Buku Ajar Keperawatan Jiwa. cetakan pertama. EGC. Jakarta

Wiramiharja, (2006). Pengantar Psikologi Klinis. Refika Aditama. Bandung

Wiknjosastro H., (2005). Ilmu Kebidanan. cetakan ketiga. Yayasan Bina Pustaka. Jakarta 